\title{
Strategi Pemenuhan Ruang Terbuka Hijau Publik di Kota Yogyakarta
}

\author{
Retna Hidayah $^{\mathrm{a}^{*}}$, Sativa ${ }^{\mathrm{a}}$, Sumarjo $\mathrm{H}^{\mathrm{a}}$ \\ Jurusan Pendidikan Teknik Sipil dan Perencanaan, Universitas Negeri Yogyakarta, Yogyakarta 55281, Indonesia
}

Keywords: green open space strategy

urban area

Kata kunci:

ruang terbuka hijau

strategi

wilayah perkotaan

\begin{abstract}
Green open space (GOS) is one of the important elements in land allocation in each region which functions to maintain the balance of the ecosystem. In accordance with statutory provisions, the quantity of GOS is set at 30\% of total area in each region covering $20 \%$ of public GOS and $10 \%$ private GOS. Most regions have not succeeded in fulfilling the stipulated quantity of GOS, including Yogyakarta City which has only reached public GOS of 17,78\% in 2014. This study aims to identify the existing public GOS and the strategies undertaken to fulfill the provision of public GOS. The descriptive approach was applied in this study and aims to gain two types of data consisting of existing area of public GOS and strategy in providing public GOS implemented in Yogyakarta City. Existing public GOS was collected by interpreting of Quickbird images which were digitized and validated by a ground survey, while the strategy data in providing public GOS was obtained through secondary sources of Spatial Planning and Land Service reports in 2018-2019. Image interpretation has resulted in data of public GOS of 220.45 ha or 6.64\%, making it still has a backlog of 435.04 ha to reach the requirement. Strategies to increase the public GOS were implemented through planting trees along roads/railways, land acquisition for green area in the settlement, and clearing river borders from building. This program increased the public GOS by $0.064 \%$, indicating that the process was quite slow, and the area obtained was not significant. Another strategy is needed by starting to think of alternative solution through private GOS.
\end{abstract}

\section{ABSTRAK}

Ruang terbuka hijau (RTH) menjadi salah satu fungsi penting dalam alokasi peruntukan setiap wilayah yang berfungsi menjaga keseimbangan ekosistem. Sesuai ketentuan peraturan perundangan, ditetapkan besaran 30\% untuk fungsi RTH dengan proporsi 20\% RTH publik dan $10 \%$ RTH privat. Dalam pelaksanaannya sebagian besar wilayah belum berhasil memenuhi capaian sesuai besaran yang ditetapkan. RTH publik Kota Yogyakarta berdasar data tahun 2014 mencapai 17,78\%. Penelitian ini bertujuan untuk mengetahui besaran RTH publik dan mengidentifikasi strategi yang dilakukan dalam rangka memenuhi penyediaan RTH publik untuk mencapai target yang disyaratkan. Menggunakan pendekatan deskriptif, penelitian ini dilakukan untuk mendapatkan dua jenis data mencakup data luas eksisting RTH publik dan data strategi penyediaan RTH. Data luas RTH diperoleh melalui interpretasi citra Quickbird yang didigitasi dan divalidasi dengan ground survey, sementara data strategi penyediaan RTH diperoleh melalui sumber sekunder dari laporan Dinas Tata Ruang dan Pertanahan 2018-2019. Interpretasi citra menghasilkan data luas RTH publik Kota Yogyakarta sebesar 220,45 ha atau sebesar 6,64\%, sehingga masih memiliki backlog RTH publik seluas 435.04 ha. Strategi untuk meningkatkan luas RTH publik melalui penanaman pohon di sepanjang jalan/KA, pembebasan tanah untuk area hijau di permukiman, dan pembebasan sempadan sungai dari bangunan untuk refungsi menjadi RTH yang menghasilkan kenaikan sebesar $0,063 \%$. Peningkatan yang terjadi cukup lambat dan luasan yang diperoleh belum mampu menambah luasan RTH publik secara signifikan. Diperlukan strategi lain untuk meningkatkan RTH dengan mulai berpikir alternatif melalui peningkatan RTH privat.

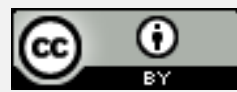

This is an open access article under the CC-BY license. 


\section{Pendahuluan}

Ruang terbuka hijau (RTH) menjadi elemen penting dalam menjaga keseimbangan ekosistem lingkungan. Penyediaannya didukung oleh Undang-Undang Nomor 26 Tahun 2007 tentang Penataan Ruang yang mensyaratkan setiap unit wilayah perencanaan untuk menyediakan RTH sebesar $30 \%$ dari luas wilayah yang terdiri dari ruang publik sebesar $20 \%$ dan ruang privat sebesar $10 \%$ [1]. Dalam pelaksanaannya, sebagian besar wilayah perkotaan mengalami kendala dalam upaya pemenuhan. Kementrian Pekerjaan Umum dan Perumahan Rakyat (PUPR) menyebutkan bahwa dari 174 kota di Indonesia yang didata, baru 13 atau sekitar 7,5\% yang dapat memenuhi ketentuan persyaratan tersebut [2].

Permasalahan belum semua unit wilayah perencanaan berhasil mencapai kuantitas yang disyaratkan menjadi isu yang menarik untuk dikaji untuk memperoleh solusi. Kajian tentang kondisi eksisting RTH publik di area perumahan di Medan telah dilakukan untuk mengidentifikasi luasan dan aktivitas penggunaannya [3]. Identifikasi yang sama dilakukan di Surabaya yang menghasilkan kategorisasi dan tipologi RTH perkotaan [4]. Kedua kajian tersebut menggambarkan kebutuhan riel RTH baik di perumahan maupun wilayah perkotaan.

Ketersediaan dan kecukupan RTH perkotaan dengan indikasi alih lahan tinggi dikaji di Surabaya [5], Jakarta [6][7] dan Yogyakarta [8]. Hasilnya menunjukkan bahwa di ketiga kota, kuantitas RTH masih di bawah standar kebutuhan luas RTH per kapita [5][6][8] dan bertambah menghadapi tantangan perubahan iklim dengan adanya urban heat island akibat sedikitnya jumlah RTH [7]. Faktor yang mempengaruhi ketersediaan RTH ditengarai berhubungan dengan ada tidaknya alokasi mendetil yang dituangkan dalam perencanaan, tersedianya insentif disinsentif, dibentuknya fasilitator, dan adanya program inovatif yang beragam untuk penghijauan [5].

Untuk mengatasi backlog tersebut, telah dicoba dilakukan proyeksi perhitungan kebutuhan RTH baik menggunakan pendekatan prosentase luasan wilayah maupun pemenuhan kuantitas sesuai kebutuhan RTH per kapita sebagai salah satu solusi pemenuhan [8][9][10]. Kedua pendekatan tersebut dapat ditempuh untuk memperhitungkan luasan RTH ideal yang perlu disediakan pada suatu wilayah sekaligus sebagai formulasi untuk mengukur ketercukupannya. Untuk kondisi wilayah dengan permasalahan yang kompleks, pemenuhan RTH dengan pendekatan $30 \%$ luas wilayah lebih sesuai dibanding dengan pendekatan pemenuhan sesuai jumlah penduduk [9].

Dari beberapa studi terkait pemenuhan RTH yang telah dilakukan di atas, dapat digambarkan bahwa permasalahan penyediaan RTH merupakan permasalahan yang kompleks menyangkut aspek teknis, ekonomi, dan kebijakan [9]. Strategi penyelesaian solusi yang bersifat khusus untuk memenuhi kuantitas RTH yang disyaratkan akan ditentukan sesuai dengan sifat dan karakteristik wilayah serta arahan kebijakan setempat.

Strategi yang ditawarkan Surabaya Timur yang memiliki RTH 7,14\% [5] dengan karakteristik alih lahan tinggi dan tanah milik pemerintah terbatas dilakukan salah satunya dengan mengatur ulang penggunaan area SPBU dengan menambahkan jalur hijau sebagai bagian RTH [11]. Jakarta Utara dengan karakteristik kepadatan tinggi, alih lahan tinggi, tanah milik pemerintah terbatas, dan lahan kosong minimal sementara kuantitas RTH baru mencapai $5 \%$, mengembangkan kombinasi beberapa strategi untuk meningkatkan kuantitas RTH.

Strategi itu mencakup: (a) meningkatkan RTH privat dengan menerbitkan IMB bagi bangunan privat yang menyediakan RTH, (b) membebaskan tanah milik masyarakat untuk difungsikan sebagai RTH, (c) mengoptimalkan median jalan dan jalur sepanjang jalan untuk jalur hijau; dan (d) mengembangkan pembuatan roof garden pada bangunan publik [12]. Kota-kota lain dengan alih lahan tinggi atau ketersediaan tanah terbatas perlu mengembangkan strategi teknis sebagai solusi mendasar penyediaan RTH yang berkesesuaian dengan karakter dan kebijakan wilayah.

Kota Yogyakarta sebagai wilayah perkotaan dengan karakteristik ketersediaan tanah terbatas tak lepas dari permasalahan penyediaan kuantitas RTH. Pada tahun 2014, besaran RTH mencapai 17,78\% mencakup RTH publik sebesar 10,03\% dan RTH privat 7,75\% [8]. Laporan Dinas Lingkungan Hidup Kota Yogyakarta menyebutkan bahwa luas RTH Kota Yogyakarta mencapai 610,99 ha atau setara dengan $18,8 \%$ mencakup ruang privat sebesar $12 \%$ dan ruang publik sebesar $6,8 \%$. Kedua data menunjukkan jumlah RTH Kota Yogyakarta masih di bawah angka yang disyaratkan. Menjadi penting bagi Kota Yogyakarta untuk mengidentifikasi potensipotensi dan strategi bersifat teknis sebagai solusi mendasar untuk meningkatkan penyediaan RTH publik. Kajian ini bertujuan untuk mengetahui luas RTH publik terkini dan mengidentifikasi strategi yang dilakukan Kota 
Yogyakarta sebagai upaya pemenuhan kuantitas RTH publik sesuai yang disyaratkan.

\subsection{Gagasan RTH}

Ruang terbuka sebagai area fungsional wilayah perencaaan mencakup ruang terbuka hijau (RTH) dan ruang terbuka non-hijau. Area terbuka non-hijau dapat berupa ruang terbuka yang diperkeras (paved open space) maupun ruang terbuka biru (RTB) yang berupa permukaan sungai, danau, dan daerah-daerah yang difungsikan sebagai area resapan air dan penyimpanan air atau retensi [1].

RTH didefinisikan sebagai area memanjang/jalur atau mengelompok, yang penggunaannya lebih bersifat terbuka, tempat tumbuh tanaman, baik yang tumbuh secara alamaniah maupun yang sengaja ditanam [1]. Secara fungsional, RTH digagas untuk memberikan manfaat ekologis, sosial budaya, arsitektural yang membawa dampak pada terpenuhinya kesejahteraan masyarakat [13][14].

Alokasi dan distribusi RTH pada setiap wilayah perencanaan tergantung pada jumlah dan sebaran penduduk dan hirarki pelayanannya yang disesuaikan dengan rencana struktur dan pola ruang wilayah, daya dukung alamiah, serta arah perkembangan wilayah. Gambar 1 menunjukkan alokasi dan proporsi masingmasing RTH, baik dalam bentuk RTH privat maupun publik.

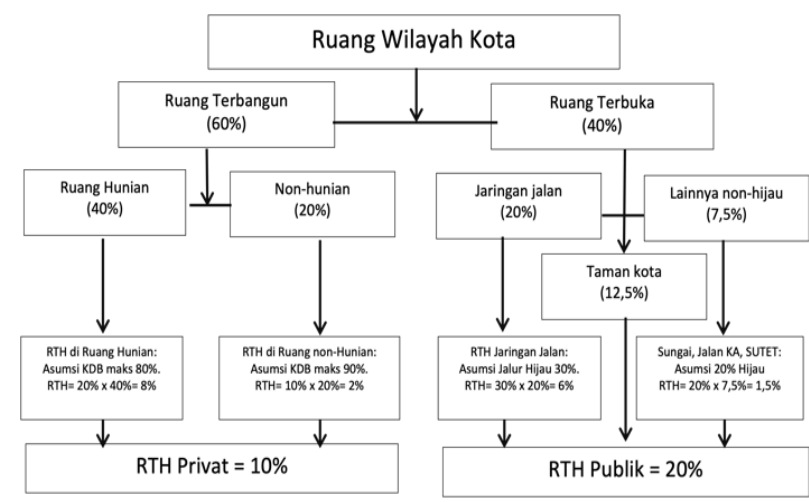

Gambar 1. Alokasi dan distribusi ruang wilayah kota

Dalam suatu wilayah, RTH publik yang dapat berbentuk taman dan jalur hijau pada area jaringan jalan, jalan KA, sungai, dan SUTET harus direncanakan minimal sebesar $20 \%$ dari luas wilayah atau lebih luas, sementara RTH privat menjadi RTH yang menjadi nilai tambah terbentuknya kualitas lingkungan wilayah [14]. Hal ini berarti bahwa, penyediaan RTH publik dalam sebuah wilayah menjadi prioritas utama untuk dicapai dalam rangka memenuhi ketersediaan RTH sebuah wilayah.

\subsection{Permasalahan Penyediaan RTH}

Secara umum di beberapa kota besar di Indonesia menunjukkan telah terjadi kecenderungan penurunan jumlah RTH. Selama tiga puluh tahun terakhir penurunan secara signifikan telah terjadi di Jakarta, Surabaya, Medan, dan Bandung dari 35\% di tahun 1970-an menjadi hanya sekitar $10 \%$ pada tahun 2010-an akibat terjadi konversi RTH menjadi fungsi infrastruktur [14].

Permasalahan tidak terpenuhinya kuantitas RTH publik di banyak wilayah disebabkan banyak faktor. Faktor tersebut secara umum mencakup aspek teknis, ekonomi, dan kebijakan serta politik [9]. Aspek teknis berhubungan dengan alih fungsi lahan sebagai konsekuensi pertumbuhan penduduk yang mendorong pemerintah maupun swasta untuk membangun sarana prasarana untuk mencukupi kebutuhan masyarakat. Termasuk aspek teknis adalah pentingnya inovasi teknis untuk mengoptimalkan sumber daya dan usaha kreatif untuk menyediakan RTH yang dapat mendukung keseimbangan ekosistem wilayah terutama bagi wilayah dengan lahan terbatas sementara pertumbuhannya cepat [13].

Aspek ekonomi berhubungan dan berkaitan erat dengan faktor kendala dalam pembiayaan dalam usaha penyediaan lahan. Problem utama penyediaan lahan RTH di wilayah perkotaan adalah terbatasnya tanah yang dikuasai oleh pemerintah sementara untuk membebaskan tanah juga memerlukan biaya yang tidak sedikit [9][12].

Belum tersedianya rencana detil yang dituangkan dalam perencanaan -Rencana Detil Tata Ruang (RDTR)- yang mengatur alokasi RTH dengan rinci di setiap wilayah menjadi salah satu faktor penyebab berikutnya [9][14] yang terkait dengan aspek kebijakan. Dari 514 kabupaten/kota yang didata, 40 di antaranya atau sekitar $7,8 \%$ telah menyusun RDTR sementara 92,2\% kabupaten/kota belum memilikinya [15]. Ketiadaan alokasi detil dalam perencanaan akan membuka peluang terjadinya alih fungsi yang tidak terkendali.

Aspek terakhir yang menjadi kendala penyediaan RTH adalah lemahnya kemauan politik pemangku kebijakan terutama dalam aspek pengendalian dan pengawasan [14][12] dan kurang solidnya komitmen menerapkan kebijakan RTH yang berlaku saat ini [9]. Selain lemahnya pengawasan dalam penggunaan lahan, kurangnya partisipasi aktif masyarakat sehingga belum terlibat 
maksimal dalam proses penyediaan RTH menjadi tantangan lain [16]. Adanya praktik pembangunan yang dilaksanakan secara parsial dan tidak terintegrasi antar sektor terutama dalam administrasi dan adanya peraturan yang masih bersifat formulatif juga menimbulkan masalah dalam penerapan di lapangan [13][12]. Apalagi penyediaan RTH dianggap tidak mendatangkan keuntungan finansial dalam jangka pendek sehingga tidak menarik bagi pelaku pembangunan [14].

\subsection{Strategi Penyediaan RTH}

Kebijakan umum untuk menyediakan ruang terbuka hijau di Indonesia telah berkembang dari waktu ke waktu. Setidaknya terdapat tiga strategi kebijakan yang berimplikasi pada strategi teknis yang ditempuh untuk menyediakan ruang terbuka hijau pada wilayah perencanaan [14]. Ketiga strategi tersebut adalah (a) mengalokasikan fungsi kawasan lindung dan melakukan perlindungan terhadap kawasan tersebut; (b) memanfaatkan jalur pada jaringan jalan dan utilitas sebagai sarana penyediaan jalur hijau; (c) melakukan pengaturan kepadatan bangunan.

Alokasi kawasan lindung dapat dilakukan dengan menyediakan hutan kota dengan membebaskan daerah sempadan sungai dari bangunan [17] dan memulihkan lahan yang telah beralih fungsi menjadi fungsi RTH kembali. Memulihkan SPBU kembali menjadi RTH dilakukan di Jakarta [17] dan Surabaya [11] dan memberikan dampak yang cukup signifikan baik secara teknis dan komitmen melakukan pengendalian. Kota Makasar juga telah menetapkan ruang hijau dalam bentuk lahan wisata, sempadan, rawa, lahan konservasi sebagai kawasan lindung sebesar $22 \%$ untuk penyediaan RTH [14]. Strategi kedua dapat dilaksanakan dengan mengoptimalkan pembentukan koridor jalur hijau di sepanjang jalur jalan, jalan KA, pedestrian, sempadan sungai, tepidan badan air, dan SUTET [8][14]. Strategi terakhir dapat dilakukan dengan mengatur kepadatan dengan menetapkan $\mathrm{KDH}$ minimal $20 \%$ pada kawasan pusat [8].

\section{Metode}

Penelitian ini dilakukan di Kota Yogyakarta yang mencakup 14 Kecamatan dengan luas total lahan sebesar 3.277, 48 ha. Dua jenis data dikoleksi mencakup data luas eksisting RTH publik dan data strategi yang diimplementasikan Kota Yogyakarta untuk meningkatkan penyediaan RTH publik. Data luas eksisting RTH publik diperoleh melalui interpretasi citra Quickbird yang didigitasi dalam peta ArcGis sebagai data vektor dalam bentuk area. Hasil interpretasi dibandingkan dengan data lapangan melalui ground survey sehingga diperoleh data fungsi eksisting dan luas RTH publik yang tervalidasi. Sementara data strategi penyediaan RTH publik diperoleh dari data sekunder dalam bentuk laporan kajian Dinas Tata Ruang dan Pertanahan Kota Yogyakarta 2018-2019. Strategi penyediaan RTH yang didata adalah strategi yang diterapkan pasca pengesahan RDTR dan Peraturan Zonasi Kota Yogyakarta 2015-2035.



Gambar 2. Pemanfaatan ruang Kota Yogyakarta berdasar hasil survei 2019 


\section{Hasil}

Sesuai interpretasi citra Quickbird yang dipetakan dalam ArcGis dan divalidasi dengan ground check diperoleh data pemanfaatan ruang Kota Yogyakarta untuk seluruh fungsi sebagaimana tergambar dalam Gambar 2.

Tabel 1. Pemanfaatan ruang Kota Yogyakarta 2019

\begin{tabular}{lcc}
\hline Fungsi ruang & Luas ruang & $\%$ \\
\hline Hunian & 1615,92 & 49,30 \\
Perdagangan dan Jasa & 641,71 & 19,58 \\
Perkantoran & 92,99 & 2,84 \\
Industri & 9,35 & 0,29 \\
Sarana Pendidikan & 183,76 & 5,61 \\
Sarana Kesehatan dan Agama & 59,47 & 1,81 \\
Sarana OR dan Rekreasi & 13,90 & 0,42 \\
Sarana Transportasi & 39,30 & 1,20 \\
Pariwisata & 39,54 & 1,21 \\
Cagar Budaya & 25,56 & 0,78 \\
RTH & 71,69 & 2,18 \\
Sempadan Sungai & 33,65 & 1,03 \\
Sungai & 38,39 & 1,17 \\
Jalan & 247,20 & 7,54 \\
Lahan kosong & 75,24 & 2,30 \\
Sawah dan tanah produktif & 89,85 & 2,74 \\
Total & 3277,48 & 100 \\
\hline
\end{tabular}

Pemanfaatan lahan sebagaimana ditunjukkan dalam Tabel 1 sebagian besar digunakan untuk hunian sebesar 1.615,92 ha atau sebesar $49,30 \%$. Sementara area terbangun mencakup fungsi hunian, perdagangan jasa, perkantoran, sarana pendidikan, sarana kesehatan dan agama, sarana OR dan rekreasi, serta pariwisata mencapai luas 2.695,94 ha atau seluas $82,26 \%$ dari total lahan Kota Yogyakarta.

Tabel 2. RTH publik Kota Yogyakarta 2019

\begin{tabular}{lcc}
\hline Fungsi RTH & Luas ruang (ha) & $\% *$ \\
\hline Taman kota/rekreasi & 19,99 & 0,61 \\
Lapangan OR & 17,58 & 0,54 \\
Jalur hijau sepanjang jalan/KA & 37,44 & 1,14 \\
Area hijau/taman permukiman & 25,83 & 0,79 \\
Pemakaman umum & 31,92 & 0,97 \\
Parkir terbuka & 33,72 & 0,95 \\
Sempadan sungai & 33,85 & 1,03 \\
Kebun binatang & 20,12 & 0,61 \\
Total & 220,45 & 6,64 \\
\hline *prosentase dihitung terhadap luas total Kota Yogyakarta 3.277,48 ha
\end{tabular}

Untuk luasan fungsi RTH publik dapat dihitung dengan menjumlahkan data RTH (mencakup taman kota/rekreasi, lapangan OR, area hijau/taman kampung) dan RTH khusus (pemakaman umum) sesuai proporsi pada Tabel 1 ditambahkan dengan data luasan jalur hijau sepanjang jalan dan jalan KA, parkir terbuka, sempadan sungai, dan kebun binatang diperoleh luasan RTH Kota Yogyakarta sebesar 220,45 ha atau sebesar $6,64 \%$ seperti data dalam Tabel 2 .

Strategi yang diterapkan untuk meningkatkan jumlah RTH 15ublic di Kota Yogyakarta pasca penetapan RDTR dan peraturan Zonasi Kota Yogyakarta 2015-2035 dari hasil pencermatan laporan Dinas Tata Ruang dan Pertanahan, laporan Dinas Lingkungan Hidup, dan RPJMD Kota Yogyakarta 2017-2022 dilakukan sebagai berikut:

\subsection{Penanaman pohon sepanjang jalur jalan}

Panjang ruas jalan di Kota Yogyakarta sepanjang 231, 206 $\mathrm{km}$ menjadi potensi yang dimanfaatkan untuk penyediaan RTH publik dengan menambahkan jalur hijau dalam bentuk penanaman pohon perindang. Pendataan terakhir pada tahun 2019 terdapat 18882 batang pohon yang menyumbang luasan tajuk seluas 37,44 ha yang tersebar merata di sepanjang jalan sebagaimana terlihat pada Gambar 3 .

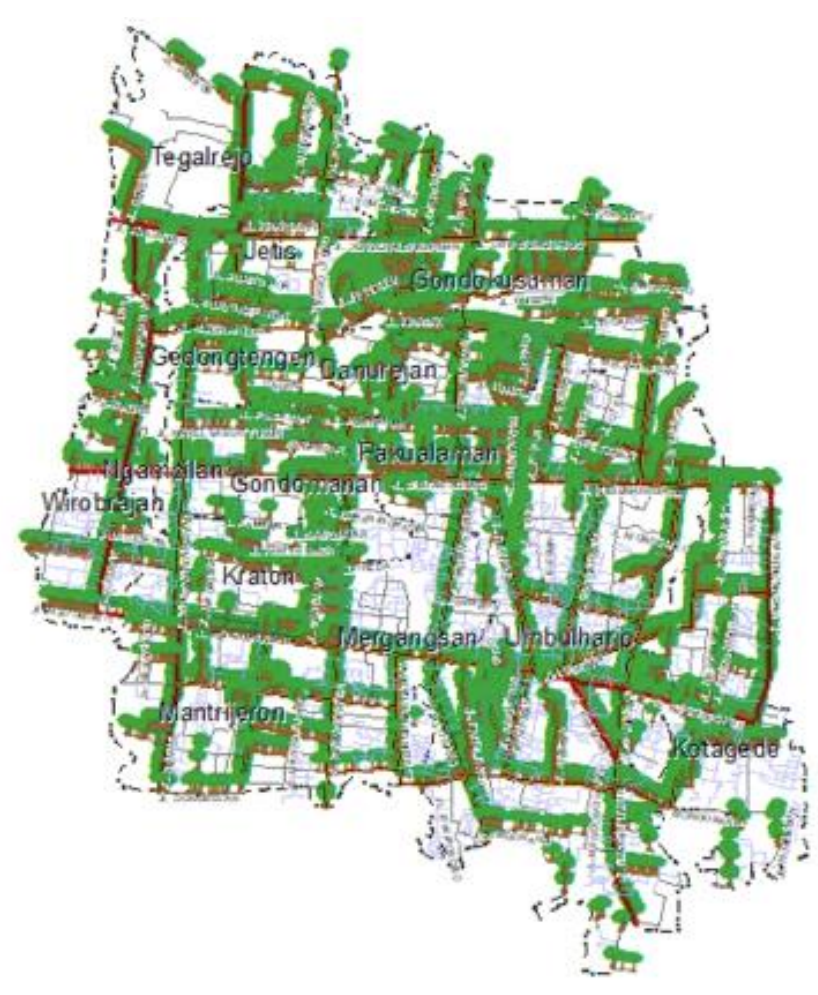

Gambar 3. Sebaran pohon perindang sebagai jalur hijau sepanjang jalur jalan

\subsection{Pembebasan tanah di dalam permukiman}

Pembebasan tanah menjadi satu strategi yang dilakukan Kota Yogyakarta sejak 2007 untuk meningkatkan jumlah RTH publik. Pada akhir 2014, jumlah RTH publik di area permukiman yang berhasil dibebaskan seluas 1,4548 ha. 
Sejak tahun 2015 sampai 2019, Kota Yogyakarta berhasil membeli 7 persil tanah di 7 lokasi yang tersebar di area permukiman dengan luas total 0,3018 has ebagaimana dalam Tabel 3. Total area RTH publik dalam permukiman yang dibebaskan untuk RTH sejak 2007 sampai 2019 menjadi 1,7566 ha.

Tabel 3. Pengadaan RTH melalui pembebasan lahan dalam area permukiman 2015-2019

\begin{tabular}{clc}
\hline Tahun pembelian & Kecamatan & Luas $\left(\mathrm{m}^{2}\right)$ \\
\hline 2015 & Umbulharjo & 813 \\
2015 & Umbulharjo & 239 \\
2015 & Umbulharjo & 283 \\
2015 & Umbulharjo & 318 \\
2017 & Gedongtengen & 172 \\
2017 & Pakualaman & 276 \\
2017 & Tegalrejo & 917 \\
Total & & 3018 \\
\hline
\end{tabular}

\subsection{Pembebasan sempadan sungai dari bangunan}

Sempadan sungai menjadi area prioritas yang dibebaskan untuk difungsikan kembali sebagai sebagai RTH publik. Tabel 4 memperlihatkan data sempadan sungai seluas
0,7802 ha di 17 lokasi sepanjang sungai yang berhasil dibebaskan dan diubah fungsinyamenjadi taman rekreatif yang memberi sumbangan pada bertambahnya luas RTH publik.

Tabel 4. Pengadaan RTH melalui pembebasan sempadan sungai dari bangunan

\begin{tabular}{llc}
\hline Sempadan sungai & Kecamatan & Luas $\left(\mathrm{m}^{2}\right)$ \\
\hline Gajah Wong & Umbulharjo & 5000 \\
Gajah Wong & Umbulharjo & 250 \\
Gajah Wong & Umbulharjo & 232 \\
Gajah Wong & Umbulharjo & 203 \\
Gajah Wong & Umbulharjo & 200 \\
Gajah Wong & Umbulharjo & 166 \\
Gajah Wong & Umbulharjo & 150 \\
Gajah Wong & Umbulharjo & 150 \\
Gajah Wong & Pakualaman & 150 \\
Winongo & Tegalrejo & 194 \\
Winongo & Tegalrejo & 170 \\
Winongo & Mantrijeron & 120 \\
Code & Jetis & 200 \\
Code & Jetis & 150 \\
Code & Jetis & 150 \\
Code & Mergangsan & 200 \\
Manunggal & Gondokusuman & 117 \\
Total & & 7802 \\
\hline
\end{tabular}

\section{Pembahasan}

Hasil interpretasi citra yang divalidasi dengan ground check menghasilkan data eksisting luasan RTH publik di Kota Yogyakarta sebesar 220, 45 ha atau seluas 6,64\% dari total luas wilayah. Dengan total luas wilayah 3277,45 ha, sesuai Undang-Undang Nomor 26 Tahun 2007 tentang Penataan Ruang, idealnya Kota Yogyakarta memiliki RTH publik dengan pendekatan perhitungan berdasar luas wilayah sebesar 20\% atau seluas 655,49 ha. Dengan luas RTH eksisting 220,45 ha, Kota Yogyakarta masih memiliki backlog seluas 435.04 ha.
Tiga strategi telah dijalankan untuk meningkatkan penyediaan kekurangan RTH publik Kota Yogyakarta dan diperoleh angka kenaikan dalam rentang 5 tahun untuk masing-masing strategi pada kategori fungsi RTH dijelaskan pada Tabel 5. Strategi penanaman pohon dapat meningkatkan luas jalur hijau sepanjang jalan/KA sekitar $0,030 \%$ dalam rentang 5 tahun. Pembebasan tanah di dalam pemukiman berpotensi meningkatkan jumlah RTH publik pada kategori area hijau/taman permukiman. Peningkatannya dalam rentang waktu 2015-2019 tercatat sebesar $0,009 \%$. Sementara pembebasan sempadan sungai dari bangunan menghasilkan kenaikan RTH publik pada kategori sempadan sungai sebesar 0,024\%. 
Dilihat dari Tabel 5 penambahan RTH publik dengan beberapa strategi tersebut di atas menunjukkan gambaran kesulitan yang dihadapi oleh Kota Yogyakarta untuk meningkatkan RTH publik. Peningkatan yang terjadi cukup lambat dan luasan yang diperoleh belum mampu menambah luasan RTH publik secara signifikan. Diperlukan strategi lain untuk meningkatkan RTH dengan mulai berpikir alternatif melalui peningkatan RTH privat [8][9][12].
Kota Yogyakarta memiliki area terbangun mencakup fungsi hunian, perdagangan jasa, perkantoran, sarana pendidikan, sarana kesehatan dan agama, sarana OR dan rekreasi, serta pariwisata mencapai luas 2.695,94 ha atau seluas $82,26 \%$ dari total lahan Kota Yogyakarta. Apabila pada setiap fungsi pada area terbangun ini ditetapkan $\mathrm{KDH} 20 \%$ [8][14] potensi RTH privat yang akan diperoleh seluas 539,188 ha.

Tabel 5. Pertambahan luas RTH publik 2015-2019

\begin{tabular}{llccc}
\hline \multicolumn{1}{c}{ Fungsi RTH } & \multicolumn{1}{c}{ Strategi } & Luas 2014 & Luas 2019 & \% kenaikan* \\
\hline Jalur hijau sepanjang jalan/KA & Penanaman pohon & 36,45 & 37,44 & 0,030 \\
Area hijau/taman permukiman & Pembebasan tanah & 25,52 & 25,83 & 0,009 \\
Sempadan sungai & Pembebasan sempadan & 33,07 & 33,85 & 0.024 \\
\hline
\end{tabular}

*prosentase dihitung terhadap luas total Kota Yogyakarta 3.277,48

\section{Simpulan}

Kajian ini bertujuan untuk mengetahui luas RTH publik terkini dan mengidentifikasi strategi yang dilakukan Kota Yogyakarta sebagai upaya pemenuhan kuantitas RTH publik sesuai yang disyaratkan. Melalui interpretasi citra citra Quickbird yang dipetakan dalam ArcGIS dan divalidasi dengan ground check diperoleh data luas RTH publik yang mencakup taman kota/rekreasi, lapangan OR, area hijau/taman permukiman, pemakaman umum, jalur hijau sepanjang jalan dan jalan KA, parkir terbuka, sempadan sungai, dan kebun binatang diperoleh luasan RTH publik Kota Yogyakarta sebesar 220,45 ha atau sebesar 6,64\%, sehingga masih memiliki backlog RTH publik seluas 435.04 ha.

Strategi yang dilaksanakan untuk meningkatkan luas RTH publik melalui penanaman pohon di jalur sepanjang jalan/KA, pembebasan tanah untuk area hijau di permukiman, dan pembebasan sempadan sungai dari bangunan untuk refungsi menjadi RTH yang menghasilkan kenaikan sebesar 0,063\%. Peningkatan yang terjadi cukup lambat dan luasan yang diperoleh belum mampu menambah luasan RTH publik secara signifikan. Diperlukan strategi lain secara teknis untuk meningkatkan RTH dengan mulai berpikir alternatif melalui peningkatan RTH privat. Strategi bersifat kebijakan juga perlu dilakukan untuk meninjau ulang proporsi RTH publik dan privat.

\section{Ucapan Terimakasih}

Terima kasih kepada Universitas Negeri Yogyakarta yang telah memberikan bantuan dana melalui Hibah Research Group untuk mendukung penelitian ini.

\section{Daftar Rujukan}

[1] Undang-Undang Republik Indonesia Nomor 26 Tahun 2007 tentang Penataan Ruang. 2007.

[2] L. Rahardian, "Ruang Terbuka Hijau yang Masih Terpinggirkan di Indonesia," Kabar24, 2019.

[3] W. Fahreza and Restu, "Analisis Ruang Terbuka Hijau Perumahan Nasional di Kota Medan," J. Geogr., vol. 8, no. 2, pp. 197-207, 2015.

[4] S. Murtini, A. Sutedjo, and I. M. Zain, "Analysis of Green Open Space in Kembangan Surabaya City," Adv. Soc. Sci. Educ. Humanit., vol. 390, pp. 162164, 2019

[5] E. F. Rini, H. Sulistyarso, and A. Pamungkas, "Factors Influencing the Availability of Green Open Space in East Surabaya," J. Archit. Environ., vol. 13, no. 1, pp. 75-92, Apr. 2014, doi: 10.12962/j2355262x.v13i1.a718.

[6] D. A. K. Sari, L. F. Widyawati, and D. Pramesti, "The Availability and Role of Urban Green Space in South Jakarta," in IOP Conference Series: Earth and Environmental Science, Mar. 2020, vol. 447, no. 1, pp. 1-10, doi: 10.1088/1755-1315/447/1/012055.

[7] R. Setiowati, H. S. Hasibuan, and R. H. Koestoer, "Green open space masterplan at Jakarta Capital City, Indonesia for climate change mitigation," IOP Conf. Ser. Earth Environ. Sci., vol. 200, no. 1, pp. 18, 2018, doi: 10.1088/1755-1315/200/1/012042.

[8] A. Ratnasari, S. R. P. Sitorus, and B. Tjahjono, "Yogyakarta Green City Planning based on Land Use and Adequacy of Green Open Space," Tata Loka, vol. 17, pp. 196-208, 2015.

[9] P. Prakoso and H. Herdiansyah, "Analisis Implementasi 30\% Ruang Terbuka Hijau di DKI Jakarta," Maj. Ilm. Globe, vol. 21, no. 1, pp. 17-26, Apr. 2019, doi: 10.24895/mig.2019.21-1.869. 
[10] W. Setyani, S. Risma, P. Sitorus, D. Dyah, and R. Panuju, "Analisis Ruang Terbuka Hijau dan Kecukupannya di Kota Depok," 2017.

[11] V. Hasyimi and D. S. A. Suroso, "Urban Green Space Development Strategy-Reconverting Gas Station To Public Parks In The City Of Surabaya, Indonesia," J. Geosci. Eng. Environ. Technol., vol. 2, no. 2, pp. 102-109, 2017, doi: 10.24273/jgeet.2017.2.2.306.

[12] N. D. P. Peramesti, "Implementasi Kebijakan Rencana Tata Ruang Wilayah dalam Penyediaan Ruang Terbuka Hijau di Kota Administrasi Jakarta Selatan Provinsi DKI Jakarta,’ J. Polit., vol. 3, no. 1, pp. 1-10, 2016.

[13] S. M. A. Haq, "Urban Green Spaces and an Integrative Approach to Sustainable Environment," J. Environ. Prot. (Irvine,. Calif)., vol. 02, no. 05, pp. 601-608, 2011, doi: 10.4236/jep.2011.25069.

[14] Prihandono Aris, "Penyediaan Ruang Terbuka Hijau (RTH) Menurut UU No. 26/2007 Tentang Penataan Ruang dan Fenomena Kebijakan Penyediaan RTH di Daerah," J. Permukim., vol. 5, no. 1, pp. 13-23, 2010 .
[15] H. Budiman, A. Mashdurohatun, and E. Suparman, "Factors Influencing the Implementation of Spatial Planning Policy in the Regions (A Case Study in Region III Cirebon)," in Advances in Economics Business and Management Research, 2020, vol. 140, no. Icleh, pp. 113-118, doi: 10.2991/aebmr.k.200513.023.

[16] R. Setyati and W. Utomo, "Implementasi Kebijakan Penataan Ruang Terbuka Hijau Kawasan Perumahan Kota Banjarbaru," J. Kebijak. Adm. Publik, vol. 19, no. 1, pp. 59-70, 2015.

[17] S. Subarudi and I. Samsoedin, "Kajian Kebijakan Hutan Kota: Studi Kasus Di Provinsi Daerah Khusus Ibukota Jakarta (Dki)," J. Anal. Kebijak. Kehutan., vol. 9, no. 2, pp. 144-153, 2012, doi: 10.20886/jakk.2012.9.2.144-153. 